\title{
Extraction of Alumina from Nawan Kaolin by Acid Leaching
}

\section{MOHAMED AHMED TANTAWY ${ }^{1,2 *}$ and ABDULAZIZ ALI ALOMARI ${ }^{2}$}

\author{
'Department of Chemistry, Faculty of Science, Minia University, Egypt. \\ 2Department of Chemistry, Faculty of Science and Arts, Mukwah, Albaha University, \\ Albaha, Saudi Arabia. \\ *Corresponding author E-mail: matantawy75@yahoo.com
}

http://dx.doi.org/10.13005/ojc/350313

(Received: April 10, 2019; Accepted: May 09, 2019)

\begin{abstract}
This paper describes the production of alumina from Nawan kaolin by acid leaching with sulfuric and hydrochloric acids. Kaolin was calcined at $850^{\circ} \mathrm{C}$ and was leached with $6 \mathrm{M}$ acid at $90^{\circ} \mathrm{C}, 5 \mathrm{M} \mathrm{NaOH}$ followed by $\mathrm{HCl}$ solutions were added to the leaching liquor and the precipitated aluminum hydroxide was converted to alumina by calcination at $900^{\circ} \mathrm{C}$. Materials were characterized by FTIR, XRD, and SEM techniques. The alumina extraction percent was determined at different leaching times (30-180 $\mathrm{min}$ ) and solid/liquid ratios $(0.05-0.15 \mathrm{~g} / \mathrm{ml})$. The purity of kaolin is about $95 \%$. The percent of extraction of alumina rapidly increases with the solid/liquid ratio up to $0.1 \mathrm{~g} / \mathrm{ml}$ then decreases thereafter. The percent of extraction of alumina is higher for $\mathrm{HCl}$ than $\mathrm{H}_{2} \mathrm{SO}_{4}$. The size of the chloride and sulfate ions is the key factor that controls the percent of extraction of alumina from calcined kaolin under the studied conditions.
\end{abstract}

Keywords: Alumina, Kaolin, Acid leaching, FTIR, XRD, SEM.

\section{INTRODUCTION}

Alumina that exists as a stable form ( $\alpha$-alumina) and in a variety of meta-stable forms including $\gamma$-alumina ${ }^{1}$ is an important industrial mineral, which can be used as an abrasive material and as adsorbent ${ }^{2}$. Alumina has been widely used in advanced technological applications including its use for the processing of high-quality insulators ${ }^{3}$, semiconductors ${ }^{4}$, microelectronics ${ }^{5}$, high-strength materials ${ }^{6}$, ceramics, refractories ${ }^{7}$, biofuel and cellfuel $^{8}$, fireproof plastics ${ }^{6}$ and high-grade polishes ${ }^{9}$. Bauxite is the main raw material used in the production of alumina by the Bayer process ${ }^{10}$. But because bauxite is not discovered in Saudi Arabia in economic quantities ${ }^{11}$, kaolinitic clay has been processed for the production of alumina alternative to bauxite ${ }^{12}$. Kaolin is widely used in the manufacture of paper, functional filler, fiberglass, and ceramics ${ }^{13}$. Kaolin is a common weathering product of many tropical and sub-tropical soils ${ }^{14}$ and consists of kaolinite mineral, $\mathrm{A}_{12} \mathrm{Si}_{2} \mathrm{O}_{5}(\mathrm{OH})_{4}$, in addition to many accessory minerals such as carbonates, feldspars, and hematite. Kaolinite is a member of the two-layer planar hydrous phyllosilicate minerals called the kaolin group ${ }^{15}$. The structural unit of kaolinite consists of single tetrahedral silica and octahedral alumina sheets bonded together by

This is an Open Access article licensed under a Creative Commons license: Attribution 4.0 International (CC- BY). Published by Oriental Scientific Publishing Company @ 2018

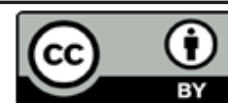


hydrogen bonding ${ }^{16}$. Leaching process is commonly used in the extractive metallurgy due to its low-cost implication, eco-friendly procedure, low-energy requirement as well as ability to treat low-grade ores $^{17}$. The three processes commonly used for extraction of alumina from clays are; (1) the acid leaching with sulfuric acid, hydrochloric acid or nitric acid to extract the alumina from calcined clay ${ }^{18,19}$. (2) The sulfatization by sintering clay with ammonium sulfate followed by extracting alumina by leaching with hot water ${ }^{20}$. (3) The alkali roasting by sintering clay with lime or soda followed by extracting alumina and silica by leaching with hot water ${ }^{21,22}$. Acids were proved more effective in aluminum extraction, than bases ${ }^{23}$. From an industrial point of view, the leaching of calcined kaolin clay in hydrochloric acid has several significant advantages including; low solubility of silica, ${ }^{24}$ the possibility of selective crystallization of $\mathrm{AlCl}_{3} \cdot 6 \mathrm{H}_{2} \mathrm{O}^{25}$ and recovery of hydrochloric acid from the waste products for reuse in the process ${ }^{26}$. There have been a lot of recent research articles has focused on the process extracting alumina from kaolin by acid leaching where the extraction rate did not exceed $90 \% \%^{27,28}$. The alumina could not be efficiently extracted from kaolin by acid leaching because of the existence of the stable structures of $\mathrm{Al}-\mathrm{O}-\mathrm{Si}$ and $\mathrm{Si}-\mathrm{O}-\mathrm{Si}^{29}$ as well as the formation of hydrated silica during leaching reaction that would hinder the contact between leaching agent and leaching nucleus ${ }^{30}$. The rate of extraction of alumina can be enhanced by calcination of kaolin in the temperature range $500-750^{\circ} \mathrm{C}$ prior to leaching to increase the reactivity of the particles by rendering the aluminum in the solid more soluble and removing organic material in the pores $^{31}$. Taking into consideration that the kinetics of the dissolution of aluminum from calcined kaolin by hydrochloric acid is a liquid-film diffusion controlled process ${ }^{32}$. Hence, the rate of extraction of alumina was enhanced by the hydrothermal leaching of calcined kaolin by hydrochloric acid reaching about $98 \%{ }^{33,34}$. As the hydrothermal leaching reduces the resistances caused by diffusion in the presence of hydrated silica ${ }^{35}$. The leaching of calcined kaolin in hydrochloric acid in the presence of fluoride ions also makes higher extractions possible at lower roasting and leaching temperatures ${ }^{36,37}$. Generally, the extraction of alumina from calcined kaolin by leaching with hydrochloric acid depends on the many variables including; fineness of kaolin, period and temperature of calcination, the concentration of hydrochloric acid, liquid/solid ratio as well as period and temperature of leaching ${ }^{15}$. A previous work was carried out to extract alumina from the Saudi kaolinitic clay of Riyadh district calcined at $700^{\circ} \mathrm{C}$ then leached by $3 \mathrm{M}$ hydrochloric acid under boiling reflux conditions with maximum alumina extraction of about $63 \% 11$. Another work involves leaching with $40 \%$ wt. sulfuric acid under boiling conditions revealed $90.9 \%$ extraction of alumina ${ }^{38}$. The objective of this paper is to study the suitability of producing alumina from kaolin deposits located nearby Nawan, Al Baha, KSA by acid leaching with sulfuric and hydrochloric acids.

\section{MATERIALS AND EXPERIMENTAL}

Kaolin was provided from the kaolin deposits located about $13 \mathrm{~km}$ to the southeast of Nawan city, Al Baha, KSA within coordinates (19029'10.27" N and $41015^{\prime 20.27 " E) ~ a s ~ i l l u s t r a t e d ~ i n ~ t h e ~ l o c a t i o n ~ m a p ~}$ in Fig. 1. The kaolin deposits cover an area of up to $10 \mathrm{~km}^{2}$ where kaolin is found in sub-surface layers covered with sand and marl deposits. Kaolin is also shown in the form of a large number of prominent divergent tongues that rise several meters above the earth's surface and extend up to 300 meters. The area contains an enormous stock of whitish kaolin. The kaolin mineral nature varies from hard stone to soft mud depending on the accessory minerals. Kaolin sample was crushed, ground and screened to particles size below $90 \mu \mathrm{m}$. Kaolin was calcined in a muffle furnace at $850^{\circ} \mathrm{C}$ for $2 \mathrm{~h}$ and was cooled down in the furnace to the room temperature. Two leaching agents were used, are $6 \mathrm{M}$ sulfuric acid $\left(\mathrm{H}_{2} \mathrm{SO}_{4}\right)$ or hydrochloric acid $(\mathrm{HCl}) .10 \mathrm{~g}$ of calcined kaolin was added to $100 \mathrm{ml}$ of the $6 \mathrm{M}$ leaching agent in a 250 $\mathrm{mL}$ round flask with condenser previously heated at $90^{\circ} \mathrm{C}$ (slurry density is $10 \mathrm{~g}$ per $100 \mathrm{ml}$ of the leaching agent) and the slurry was stirred at $500 \mathrm{rpm}$ for 3 hours. The slurry was diluted with $100 \mathrm{ml}$ of distilled water as well as was filtered using a Buchner funnel and the dealuminated residue was washed with distilled water and dried at $80^{\circ} \mathrm{C}$. The filtrate was heated to near boiling followed by the addition of an excess solution of $5 \mathrm{M} \mathrm{NaOH}$, to convert alumina into $\mathrm{NaAlO}_{2}$ to facilitate the separation of the hydroxides of iron and magnesium. After filtration, $6 \mathrm{M} \mathrm{HCl}$ was added to the $\mathrm{NaAlO}_{2}$ filtrate with stirring to adjust the $\mathrm{pH}$ to 7 , and the aluminum hydroxide precipitate 
was filtered, washed with distilled water and dried at $110^{\circ} \mathrm{C}$ overnight. Alumina $\left(\mathrm{Al}_{2} \mathrm{O}_{3}\right)$ was obtained by the calcination of aluminum hydroxide precipitate in a muffle furnace at $900^{\circ} \mathrm{C}$ for 2 hours. The leaching procedure was summarized in Fig. 2. The aluminum recovery percent was determined from the weight of alumina. Leaching of $\mathrm{Al}$ from calcined kaolin with $\mathrm{H}_{2} \mathrm{SO}_{4}$ and $\mathrm{HCl}$ at different leaching time (30, $60,90,120$ and $180 \mathrm{~min}$ ) and solid/liquid ratios $(0.05,0.10$ and $0.15 \mathrm{~g} / \mathrm{ml})$ using $6 \mathrm{M}$ acid solution at $90^{\circ} \mathrm{C}$ were studied as the leaching system was illustrated in Figure 3.

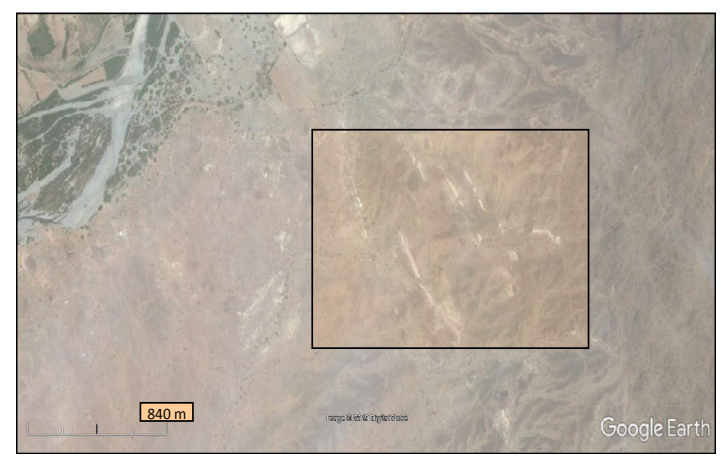

Fig. 1. Kaolin location map

The dehydroxylation of kaolin at $850^{\circ} \mathrm{C}$ approximately proceeds according to the following equation (1):

$$
\mathrm{Al}_{2} \mathrm{O}_{3} \cdot 2 \mathrm{SiO}_{2} \cdot 2 \mathrm{H}_{2} \mathrm{O}_{(\mathrm{g}} \rightarrow \mathrm{Al}_{2} \mathrm{O}_{3} \cdot 2 \mathrm{SiO}_{2(\mathrm{~g})}+2 \mathrm{H}_{2} \mathrm{O}_{(\mathrm{g}}
$$
Equation (2):

The $\mathrm{Al}_{2} \mathrm{O}_{3}$ recovery was calculated by using

$$
\% \mathrm{Al}_{2} \mathrm{O}_{3}=100 \times\left(w t / w t_{\mathrm{o}}\right)
$$

Where: $w t$ is the weight of $\mathrm{Al}_{2} \mathrm{O}_{3}$ obtained in the final step of the procedure; $w t_{0}$ is the initial weight of $\mathrm{Al}_{2} \mathrm{O}_{3}$ in calcined kaolin obtained from $\mathrm{XRF}$ results $\left(\mathrm{Al}_{2} \mathrm{O}_{3}\right.$ equals $\left.42.125 \mathrm{wt} \%\right)$. Hence, $\mathrm{wt}_{\mathrm{o}}=4.2125$, for $10 \mathrm{~g}$ calcined kaolin used in leaching.

The kaolin, calcined kaolin, dealuminated residue, and alumina were analyzed by FTIR, XRD, and SEM techniques. XRF of calcined kaolin was analyzed by Philips PW1606 X-ray fluorescence spectrometer. XRD was analyzed by Philips X-ray diffractometer PW 1370, $\mathrm{C}_{0}$. with Ni-filtered CuK $\alpha$ radiation (1.5406 $\AA$ ). Semi-quantitative phase analysis was calculated using the Bruker AXS configuration program. FTIR was traced by spectrometer Perkin Elmer FTIR System Spectrum $X$ in the range $400-4000 \mathrm{~cm}^{-1}$. TGA/DrTGA/DSC was analyzed by Netzsch STA $409 \mathrm{C} / \mathrm{CD}$ analyzer with $2^{\circ} \mathrm{C} /$ min heating rate from room temperature up to $1000^{\circ} \mathrm{C}$, under air atmosphere at $50 \mathrm{ml} / \mathrm{min}$ flow rate the hold time at the appropriate temperature is zero. SEM was analyzed by Jeol-Dsm 5400 LG apparatus.

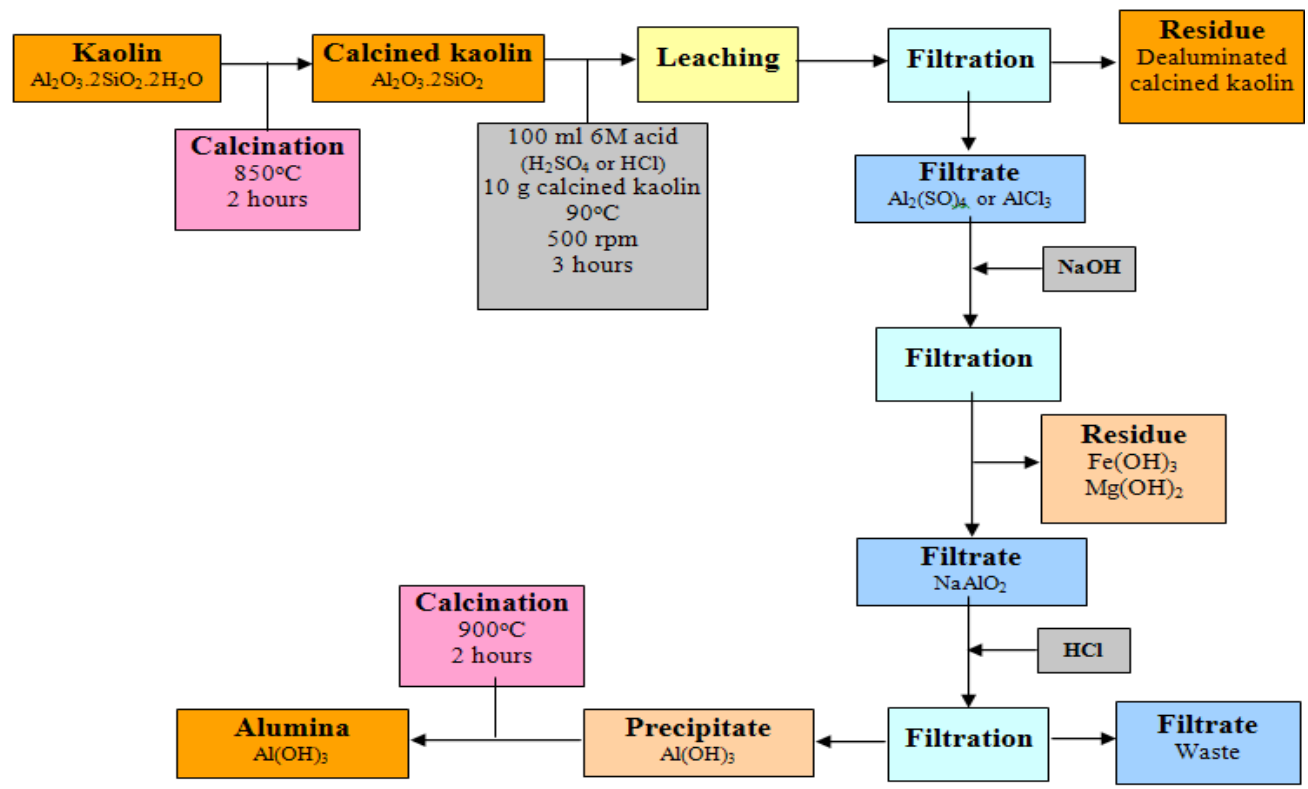

Fig. 2. Flow sheet of the proposed process 


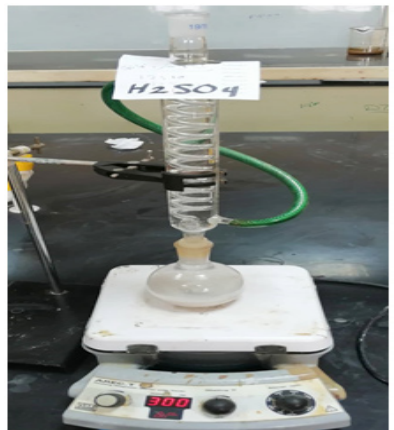

Fig. 3. Leaching system of calcined kaolin

\section{RESULTS AND DISCUSSION}

Figure 4 illustrates the thermogravimetric analysis of kaolin. The weight loss below $200^{\circ} \mathrm{C}$ is due to the loss of physically adsorbed water. The significant weight loss stage within the temperature range (350$700^{\circ} \mathrm{C}$ ) and the corresponding endothermic peak and mass signal peak at $520^{\circ} \mathrm{C}$ are attributed to the removal of structural water in kaolin ${ }^{22}$. Besides, a sharp exothermic peak at $981^{\circ} \mathrm{C}$ is assigned to the phase transformation from metakaolinite to Al-Si spinel or the mixture of $\gamma$-alumina, amorphous silica, and mullite ${ }^{39}$. Clay materials contain two kinds of structural water molecules. The water molecules present in the first coordination sphere of the interlayer ions dehydroxylate in the range $300-500^{\circ} \mathrm{C}$, whereas the structural hydroxyl groups dehydrate in the temperature range of $500-800^{\circ} \mathrm{C}^{40}$.
Table 1 illustrates the XRF analysis of calcined kaolin. The major oxide contents of kaolin are $42.1 \mathrm{wt} \% \mathrm{Al}_{2} \mathrm{O}_{3}$ and $51.3 \mathrm{wt} \% \mathrm{SiO}_{2}$ whereas the minor oxide contents are $1.2 \mathrm{wt} \% \mathrm{TiO}_{2}$ and $1.8 \mathrm{wt} \% \mathrm{Fe}_{2} \mathrm{O}_{3}$.

Figure 5 illustrates the alumina extraction percent from calcined kaolin with $\mathrm{HCl}$ and $\mathrm{H}_{2} \mathrm{SO}_{4}$ as a function of the solid/liquid ratio at different leaching times. The alumina extraction percent rapidly increases with leaching time up to 120 minutes. This is due to that as time passes, the number of acid molecules that interact with the particles of calcined kaolin increases. The alumina extraction percent then increases at a slower rate thereafter. This indicates that the leaching time should not exceed 3 hours. The alumina extraction percent rapidly increases with the solid/liquid ratio up to $0.1 \mathrm{~g} / \mathrm{ml}$ then decreases thereafter. This might be attributed to that at the lower solid/liquid ratio, the amount of leaching agent is sufficient up to the solid/liquid ratio $0.1 \mathrm{~g} / \mathrm{ml}$, thereafter, the amount of leaching agent compensation to every particle decreases with increasing the amount of solid in the leaching liquor ${ }^{41}$. The alumina extraction percent from calcined kaolin is higher for $\mathrm{HCl}$ than $\mathrm{H}_{2} \mathrm{SO}_{4}$. It can be concluded that the size of the chloride and sulfate ions is the key factor that controls the alumina extraction percent from calcined kaolin under the same leaching conditions. According to the literature, the radius of the ion, $\mathrm{R}_{\text {ion }}$, can be defined as:

$\mathrm{R}_{\text {ion }}=\mathrm{d}_{\text {ion-water }}-\mathrm{R}_{\text {water }}$

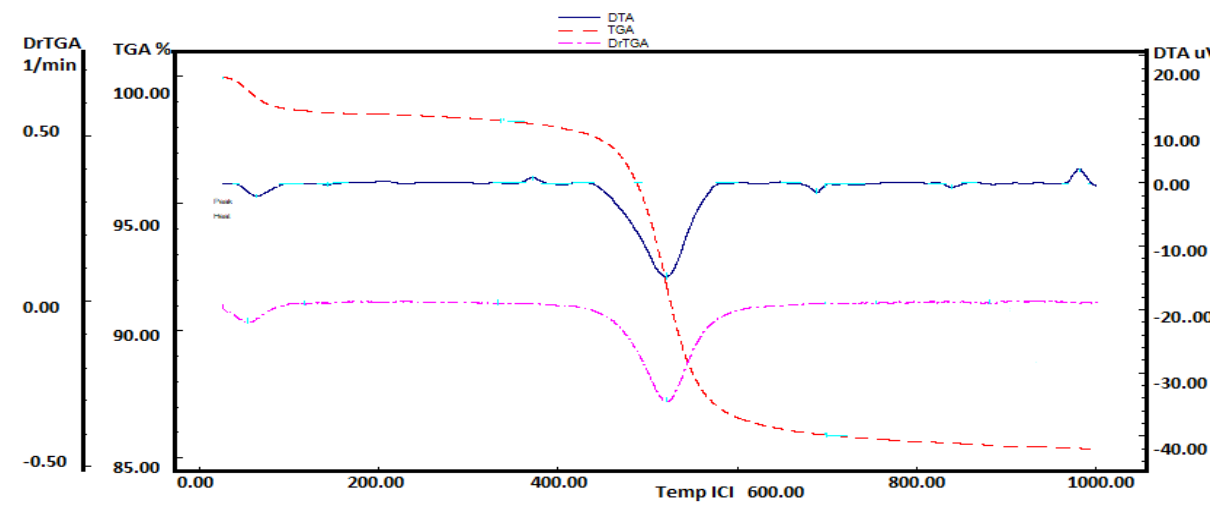

Fig. 4. TGA/DTA/Dr TGA of kaolin

Table 1: XRF analysis of calcined kaolin

\begin{tabular}{ccccccccccccc}
\hline Oxide & $\mathrm{Na}_{2} \mathrm{O}$ & $\mathrm{MgO}$ & $\mathrm{Al}_{2} \mathrm{O}_{3}$ & $\mathrm{SiO}_{2}$ & $\mathrm{P}_{2} \mathrm{O}_{5}$ & $\mathrm{SO}_{3}$ & $\mathrm{~K}_{2} \mathrm{O}$ & $\mathrm{CaO}$ & $\mathrm{TiO}_{2}$ & $\mathrm{Cr}_{2} \mathrm{O}_{3}$ & $\mathrm{Fe}_{2} \mathrm{O}_{3}$ & $\mathrm{Cl}$ \\
\hline $\mathrm{Wt} \%$ & 0.222 & 0.303 & 42.125 & 51.330 & 0.066 & 0.228 & 0.502 & 0.574 & 1.268 & 0.026 & 1.820 & 0.069 \\
\hline
\end{tabular}

Where $R_{\text {water }}$ is an appropriate distance that characterizes the radius of a water molecule, (the average of the reported value is $R_{\text {water }}=$ $0.1420 \pm 0.0005 \mathrm{~nm}$ ), and dion-water is the mean 
intermolecular distance between the ion and water molecule ${ }^{42}$. Several authors determined the ionic radii in aqueous solutions by using X-ray, electron, and neutron diffraction and Monte Carlo and molecular dynamics computer simulation methods ${ }^{43,44}$.

The reported values of the $\mathrm{Cl}-(\mathrm{O}$ water $)$ internuclear distance is of the average $0.318 \pm 0.006$

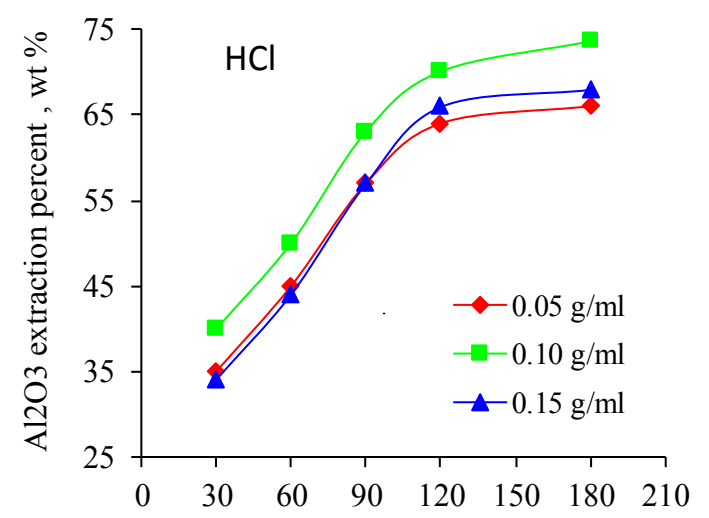

Leaching time, min $\mathrm{nm}$, whereas that of $\mathrm{S}$-(O water) is $0.381 \pm 0.007 \mathrm{~nm}^{42}$ Hence, as the chloride ion is smaller in size compared to the sulfate ion, the attack of $\mathrm{HCl}$ molecules is more aggressive than $\mathrm{H}_{2} \mathrm{SO}_{4}$ on the calcined kaolin particles under the similar conditions and gives the higher alumina extraction percent. This indicates that the optimum solid/liquid ratio is $0.1 \mathrm{~g} / \mathrm{ml}$.

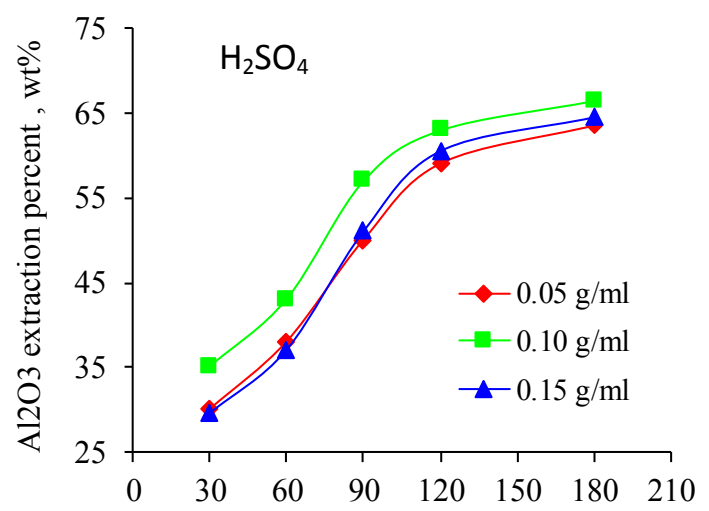

Leaching time, $\min$

Fig. 5. Alumina extraction percent from calcined kaolin with $\mathrm{HCl}$ and $\mathrm{H}_{2} \mathrm{SO}_{4}$ as a function of solid/liquid ratio at different leaching times

Figure 6 illustrates the XRD patterns of kaolin, calcined kaolin, dealuminated residue, and $\mathrm{Al}_{2} \mathrm{O}_{3}$. Kaolin consists of $67.0 \mathrm{wt} \%$ kaolinite and $29.5 \mathrm{wt} \%$ quartz and traces of anatase $\left(\mathrm{TiO}_{2}\right)$. The calcination of kaolin, leads to the dehydroxylation of the kaolinite mineral, resulting in the formation of amorphous dehydroxylated aluminosilicate phases with the survival of quartz. The acid leaching of calcined kaolin by $\mathrm{H}_{2} \mathrm{SO}_{4}$ or $\mathrm{HCl}$ selectively dissolves alumina without dissolving silica from the amorphous dehydroxylated aluminosilicate phases. The XRD pattern of alumina shows that the two peaks at $2 \theta=37.8^{\circ}$ and $45.7^{\circ}$ are assigned to (311) and (400) diffractions of $\gamma-\mathrm{Al}_{2} \mathrm{O}_{3}{ }^{45}$.

Figure 7 illustrates the FTIR spectra of kaolin, calcined kaolin, dealuminated residue, and $\mathrm{Al}_{2} \mathrm{O}_{3}$. In the FTIR spectrum of kaolin, the band at $1105 \mathrm{~cm}^{-1}$ is attributed to the asymmetric stretching vibrations of $\mathrm{Si}-\mathrm{O}-\mathrm{Si}$, the band at $1025 \mathrm{~cm}^{-1}$ is due to the alternating stretching vibrations of $\mathrm{Si}-\mathrm{O}-\mathrm{Si}$ and $\mathrm{Al}-\mathrm{O}-\mathrm{Al}^{46}$. The band at $908 \mathrm{~cm}^{-1}$ is attributed to the bending Al-O-H vibrations (hydroxyl groups sitting on the alumina faces) ${ }^{46}$. The band at $683 \mathrm{~cm}^{-1}$ corresponds to the symmetric Si-O-Si stretching vibration ${ }^{47}$.

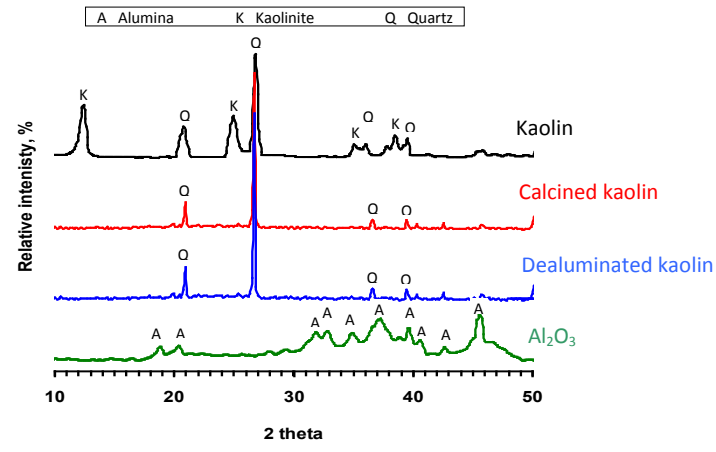

Fig. 6. XRD patterns of kaolin, calcined kaolin, delauminated kaolin and $\mathrm{Al}_{2} \mathrm{O}_{3}$

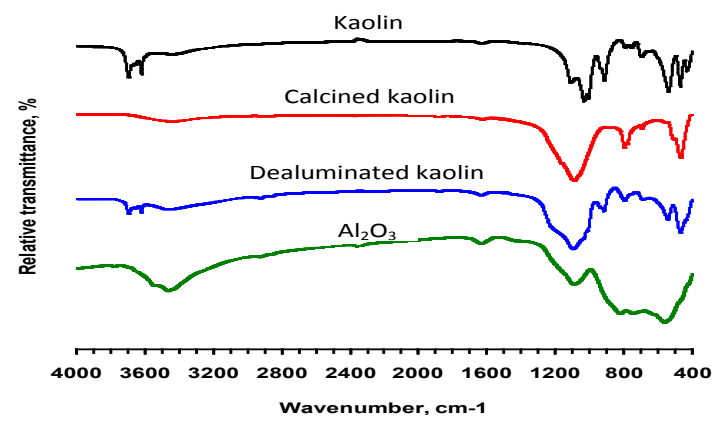

Fig. 7. FTIR spectra of kaolin, calcined kaolin, delauminated kaolin and $\mathrm{Al}_{2} \mathrm{O}_{3}$ 
The band at $532 \mathrm{~cm}^{-1}$ is due to $\mathrm{Al}{ }^{4+}-\mathrm{O}-\mathrm{Si}$ vibrations, where $\mathrm{Al}^{4+}$ is in octahedral coordination ${ }^{46}$. The band at $465 \mathrm{~cm}^{-1}$ is responsible for the bending O-Si-O vibration ${ }^{48}$. The bands at 3700 and 3621 $\mathrm{cm}^{-1}$ are due to elongation vibrations of $\mathrm{OH}$ - groups sitting at the edges of the kaolin platelets ${ }^{49}$. The band at $3618 \mathrm{~cm}^{-1}$ is connected with the internal $\mathrm{OH}$ - groups ${ }^{49}$. The bands at 1610 and $3691 \mathrm{~cm}^{-1}$ are responsible for the bending $\mathrm{HO}-\mathrm{H}$ vibrations of adsorbed water molecules49. In the FTIR spectrum of calcined kaolin, the bands at 792, 686 and 459 $\mathrm{cm}^{-1}$ are characteristic for quartz and attribute to the Si-O-Si symmetric stretching vibration and $\mathrm{O}-\mathrm{Si}-\mathrm{O}$ bending vibrations $\mathrm{s}^{50}$. The bands at 3407 and $1610 \mathrm{~cm}^{-1}$ are attributed to stretching and bending vibrations of $\mathrm{OH}$ - groups of absorbed water ${ }^{51}$. The formation of the band at $1090 \mathrm{~cm}^{-1}$ is attributed to the $\mathrm{Si}-\mathrm{O}$ stretching vibrations of amorphous $\mathrm{SiO}_{2}{ }^{51}$ proves the formation of metakaolinite structure ${ }^{52}$. In the FTIR spectrum of dealuminated residue, the band at $536 \mathrm{~cm}^{-1}$ is due to $\mathrm{Al}^{4+}-\mathrm{O}-\mathrm{Si}$ vibrations in the octahedral coordination ${ }^{50}$. The bands at 779,671 and $459 \mathrm{~cm}^{-1}$ are characteristic for quartz due to the symmetric Si-O-Si stretching vibration and O-Si-O bending vibrations $\mathrm{s}^{46,50}$. The new absorption band at $910 \mathrm{~cm}^{-1}$ is due to the Si-O-H bending vibrations of the hydrated silica formed in a leaching process that involves the replacement of $\mathrm{Al}$ of $\mathrm{Al}-\mathrm{O}-\mathrm{Si}$ structure with $\mathrm{H}^{+53}$. The band at $3616 \mathrm{~cm}^{-1}$ is attributed to the internal $\mathrm{OH}$ - groups ${ }^{49}$. The bands at 1620 and $3685 \mathrm{~cm}^{-1}$ are responsible for the bending $\mathrm{HO}-\mathrm{H}$ vibrations of adsorbed water molecules ${ }^{49}$. The band at $1086 \mathrm{~cm}^{-1}$ is attributed to Si-O-Si asymmetric stretching vibrations $\mathrm{s}^{54}$. This band is shifted to a lower frequency as an indication for lowering the degree of polymerization of the silica network ${ }^{55}$ may be due to the influence of acid leaching. The FTIR spectrum of alumina, the large broadband at $400-1000 \mathrm{~cm}^{-1}$ is attributed to Al-O-Al stretching vibration arising from the distribution of alumina among the octahedral and tetrahedral sites $^{56}$. The bands at 808,722 , and 562 $\mathrm{cm}^{-1}$ are attributed to vibration of the Al-O bonds of pseudo-boehmite structure ${ }^{57}$. The band at $1080 \mathrm{~cm}^{-1}$ corresponds to the Al-O-H mode of boehmite ${ }^{57}$. The very large band centered at 3440 and $3540 \mathrm{~cm}^{-1}$ ascribed to stretching vibration of bonded $\mathrm{OH}$ - groups, isolated $\mathrm{OH}$ - groups, and stretching vibrations of adsorbed water molecules. The band at $1614 \mathrm{~cm}^{-1}$ is due to bending of adsorbed water molecules ${ }^{58}$.
Figure 8 illustrates the SEM micrographs of kaolin, calcined kaolin and $\mathrm{Al}_{2} \mathrm{O}_{3}$. The SEM micrograph of the kaolin shows hexagonal platelets of kaolinite mineral in addition to a small proportion of halloysite tubular crystals ${ }^{59}$. After being thermally treated, metakaolin attains its original shape. Therefore, the thermal treatment does not drastically modify the morphology ${ }^{60}$. The SEM micrograph of kaolin illustrates the existence of flat plate particles with sizes of around $1 \mu \mathrm{m}$ was observed, where the flat particles stacked together. Although kaolin was calcined no changes can be observed by microscopic examination. SEM micrograph of the alumina illustrates the appearance of octahedral alumina crystals ${ }^{61}$.

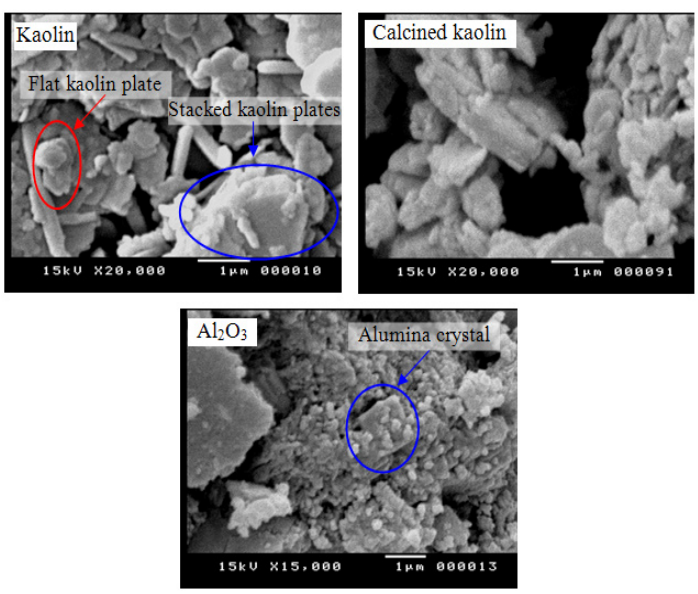

Fig. 8. SEM photographs of kaolin, calcined kaolin and $\mathrm{Al}_{2} \mathrm{O}_{3}$

\section{CONCLUSION}

This paper studied the suitability of kaolin deposits located nearby Nawan, Al Baha, KSA for the production of alumina by acid leaching with 6 $M$ sulfuric acid or hydrochloric acid for $30-180 \mathrm{~min}$ and solid/liquid ratios $0.05-0.15 \mathrm{~g} / \mathrm{ml}$. The optimum conditions for the Al recovery from the studied kaolin include the grinding and screening of kaolin to particles size below $90 \mu \mathrm{m}$, calcination of kaolin at $850^{\circ} \mathrm{C}$ for $2 \mathrm{~h}$ leaching with $6 \mathrm{M} \mathrm{HCl}$ with the solid/ liquid ratio of $0.1 \mathrm{~g} / \mathrm{ml}$ for $3 \mathrm{~h}$ at $90^{\circ} \mathrm{C}$ and $500 \mathrm{rpm}$ in a reflux system. The percent of aluminum recovery from calcined kaolin under the studied conditions reaches about $75 \mathrm{wt} \%$.

\section{ACKNOWLEDGMENT}

The authors would acknowledge Albaha University for facilitating the performance of this 
study in the laboratories of the chemistry department, faculty of science and arts, Mukwah.

\section{Confilicts of Interest}

The authors declare no confilict of interest.

\section{REFERENCES}

1. Wang, S. Li, X., Wang, S., Li, Y., Zhai, Y., Synthesis of gamma-alumina via precipitation in ethanol. Material Letters., 2009, 62, 3552-3554.

2. Salahudeen, N., Ahmed, AS., Al-Muhtaseb, AH., Dauda, M., Waziri, SM, Baba, Y. \& Jibril, BY., Synthesis of gamma alumina from Kankara kaolin using a novel technique. Applied Clay Science., 2015, 105-106, 170-177.

3. Ueki, Y., Kunugi, T., Morley, NB., Abdou, MA., Electrical insulation test of alumina coating fabricated by sol-gel method in molten PbLi pool. Fusion Engineering Design., 2010, 85, 1824-1828.

4. Lee, SJ., Kim, HS., Park, N., Lee, TJ., Kang, M., Low temperature synthesis of alpha alumina from aluminum hydroxide hydrothermally synthesized using $\left[\mathrm{Al}\left(\mathrm{C}_{2} \mathrm{O}_{4}\right)\right.$ $\mathrm{x}(\mathrm{OH}) \mathrm{y}$. complexes. Chemical Engineering Journal., 2013, 230, 351-360.

5. Kerness, ND., Hossain, TZ., Mcguire, SC., Impurity study of alumina and aluminum nitride ceramics: microelectronics packaging applications. Applied Radiation Isotopes., 1997, 48, 5-9.

6. Lee, SO., Jung, KH., Oh, CJ., Lee, YH., Myong, TT., Kim, J., Precipitation of fine aluminum hydroxide from Bayer liquors. Hydrometallurgy., 2009, 98, 156-161.

7. Andrews, A., ElsieNsiah-Baafi, S., Gawu, Y., Olubambi, PA., Synthesis of high alumina refractories from lithomargic clay. Ceramics International., 2014, 40, 6071-6075.

8. Phung, TK., Lagazzo, A., Crespo, MAR., Scribano, VS., Busca, G., A study of commercial transition aluminas and of their catalytic activity in the dehydration of ethanol. Journal of Catalysis., 2014, 311, 102-113.

9. Lei, H., Wu, X., Chen, R., Preparation of porous alumina abrasives and their chemical mechanical polishing behavior. Thin Solid Films, 2012, 520, 2868-2872.

10. Hosseini, SA., Niaei, A., Dariush, S., Production of $-\mathrm{Al}_{2} \mathrm{O}_{3}$ from kaolin. Open Journal of Physical Chemistry., 2012, 2011(1), 23-27.

11. Al-Zahrani, AA., Abdul-Majid, MH., Extraction of alumina from local clays by hydrochloric acid process. JKAU: Engineering Science., 2009, 20(2), 29-41.

12. Hoffman, Jl., Leslie, RT., Caul, HJ., Clark, LJ., Hoffman, JD., Development of a hydrochloric acid process for the production of alumina from clay. U.S. Department of Commerce, National Bureau of Standards, RP 1756: Washington, DC, USA., 1946, 37, 409-428.

13. Wang BK., Ding H., Deng YX., Characterization of calcined kaolin/TiO2 composite particle material prepared by mechano-chemical method. Journal of Wuhan University of Technology and Material Science Education., 2010, 25(5), 765-769.

14. Hughes, JC., Gilkes, RJ., Hart, RD., Intercalation of reference and soil kaolins in relation to physico-chemical and structural properties. Applied Clay Science., 2009, 45, 24-35.

15. Bergaya, F., Lagaly, G., $2^{\text {nd }}$ edition, Handbook of clay science. Elsevier Ltd., 2013, 2, 6-29.

16. Al-Ajeel, AA., Al-Sindy, SI., Alumina recovery from Iraqi kaolinitic clay by hydrochloric acid route. Iraqi Bulletin of Geology and Mining., 2006, 2(1), 67-76.

17. Ajemba, RO., Onukwuli, OD., Determination of the optimum dissolution optimum dissolution conditions of Uukpor clay in hydrochloric acid using response surface methodology. International Journal of Engineering Research Application., 2012, 2(5), 732-742.

18. Olaremu, AG., Sequential leaching for the production of alumina from a Nigerian clay. International Journal of Engineering Technology Management and Applied Sciences., 2015, 3(7), 2349-4476.

19. Toama, HZ., Al-Ajeel, AA., Jumaah, AH., Studying the efficiency of lime-soda sinter process to extract alumina from colored kaolinite ores using factorial technique of design of experiments. Engineering Technology Journal., 2018, 36(A), 500-508.

20. Numluk, P., Chaisena, A., Acid and ammonium sulfate leaching of alumina from lampang clay. European Journal of Chemistry., 2012, 9(3), 1364-1372. 
21. Guo, Y., Yan, K., Cui, L., Cheng, F., Lou, H.H., Effect of $\mathrm{Na}_{2} \mathrm{CO}_{3}$ additive on the activation of coal gangue for alumina extraction. International Journal of Mineral Process., 2014, 131, 51-57.

22. Zhang, D., Pan, X., Yu, H., Zhai, Y., Mineral transition of calcium aluminate clinker during high-temperature sintering with low-lime dosage. Journal of Materials Science and Technology., 2015, 31(12), 1244-1250.

23. Kyriakogona, K., Giannopoulou, I., Panias, D., Extraction of aluminum from kaolin: a comparative study of hydrometallurgical processes. Proceedings of the $3^{\text {rd }}$ World Congress on Mechanical, Chemical, and Material Engineering (MCM'17) Rome., 2017, 8-10.

24. Valeev, DV., Lainer, Y., Pak, VI., Decomposition of boehmite-kaolin bauxites by hydrochloric acid using preliminary calcination. Advanced materials., 2015, 4, 61-67.

25. Guo, Y., Yang, X., Cui, H., Cheng, F., Yang, F., Crystallization behavior of $\mathrm{AlCl}_{3} \cdot 6 \mathrm{H}_{2} \mathrm{O}$ in hydrochloric system. Huagong Xuebao/ CIESC Journal., 2014, 65(10), 3960-3967.

26. Demopoulos, GP., Li, Z., Becze, L., Moldoveanu, G., Cheng, TC., Harris, B., New technologies for $\mathrm{HCl}$ regeneration in chloride hydrometallurgy. World of MetallurgyERZMETALL., 2008, 61(2), 89-98.

27. Zeng, XJ., Wang, Y., Study on alumina extraction from kaolin tailings by the hydrothermal-assisted two times acid extracting process. Metal and Nonmetal Mines., 2012, 35(5), 31-33.

28. Behera, PS., Synthesis and characterization of nano-sized $\alpha$-alumina powder from kaolin by acid leaching process. Applied Clay Science., 2017, 146, 286-290.

29. Tang, A., Su, L., Li, C., Wei, W., Effect of mechanical activation on acid-leaching of kaolin residue. Applied Clay Science., 2010, 48, 296-299.

30. Feng, J., Li, Y., Liu, S., Deng, YC., Zhou, ZF., $\mathrm{Li}$, YJ., Preparation of nano-alumina from kaolin middling ore. Metal and Nonmetal Mines., 2010, 33(5), 55-57.

31. Bengtson, KB., A technological comparison of six processes for the production of reduction-grade alumina from non-bauxite raw materials. Light Metals., 1979, 217-282.
32. Uchenna, U., Onukwuli, OD., Regina, A., Nonso, UC., Kinetics studies of hydrochloric acid leaching of alumina from Agbaja clay. International Journal of Research in Advanced Engineering and Technology., 2015, 1(1), 64-72.

33. Valeev, D., Pak, V., Mikhailova, A., GolDberg, M., Zheleznyi, M., Dorofievich, I., Lainer, Y., Bychinskii, V., Chudnenko, K., Extraction of aluminum by autoclave hydrochloric acid leaching of boehmite-kaolinite-bauxite. TMS Conference, $145^{\text {th }}$ Annual Meeting and Exhibition At: Nashville, Tennessee, USA, Light Metals., 2016, 5, 23-28.

34. Lin, M., Liu, YY., Lei, SM., Ye, Z., Pei, ZY., Li, B., High-efficiency extraction of Al from coalseries kaolinite and its kinetics by calcination and pressure acid leaching. Applied Clay Science., 2018, 161, 215-224.

35. Cheng-You, WU., Hong-Fa, YU., Zhang, $H F$., Extraction of aluminum by pressure acid-leaching method from coal fly ash. Transactions of Nonferrous Metals Society of China., 2012, 22(9), 2282-2288.

36. Gajam, SY., Raghavan, S., A kinetic model for the hydrochloric acid leaching of kolinitic clay in the presence of fluoride ions, Hydrometallurgy., 1985, 15, 143-158.

37. Bailey, NT., Chapman, RJ., The use of coal spoils as feed material for alumina recovery by acid leaching routes $\mathrm{V}$ : the effect of fluoride additions on the extraction of aluminum with hydrochloric acid. Hydrometallurgy., 1987, 18, 337-350.

38. Al-Zahrani, A., Al Zaitone, B., Production of alumina from Saudi clay by sulfuric acid leaching. International Journal of Engineering Sciences and Research Technology., 2017, 6(2), 285-293.

39. Liu, X., Liu, X., Hu, Y., Investigation of the thermal behavior and decomposition kinetics of kaolinite. Clay Mineralogy., 2015, 50(2), 199-209.

40. EIDeeb, AB., Brichkin, VN., Kurtenkov, RV., Bormotov, IS., Extraction of alumina from kaolin by a combination of pyro-and hydrometallurgical Processes. Applied Clay Science., 2019, 172, 146-154.

41. Abali, Y., Bayca, SU., Mistincik, E., Kinetics of oxalic acid leaching of tincal. Chemical Engineering Journal., 2006, 123, 25-30. 
42. Lie, GC., Clementi, EJ., Cl study of the water dimer potential surface. Journal of Chemical Physics., 1975, 62, 2195-2199.

43. Lie, GC., Clementi, E., Yoshimine, M., Ab initio studies of cyclic water clusters $\left(\mathrm{H}_{2} \mathrm{O}\right) \mathrm{n}, \mathrm{n}=1-6$. II. Analysis of many-body interactions. Journal of Chemical Physics., 1976, 64, 2314-2319.

44. Marcu, Y., Ionic radii in aqueous solutions. Chemical Review., 1988, 88, 1475-1498.

45. Rahmanpour O., Shariati, A., Nikou, MRK., New method for synthesis nano size $\gamma-\mathrm{Al}_{2} \mathrm{O}_{3}$ catalyst for dehydration of methanol to dimethyl Ether. International Journal of Chemical Engineering and Applications., 2012, 3(2), 125-128.

46. Galan, E., Aparicio, P., Miras, A., Michailidis, K., Tsirambides, A., Technical properties of compounded kaolin sample from Griva (Macedonia, Greece). Applied Clay Science., 1996, 10, 477-490.

47. Baltakys K., Jauberthie R., Siauciunas R., Kaminskas R., Influence of modification of $\mathrm{SiO}_{2}$ on the formation of calcium silicate hydrate. Material Science Poland., 2007, 25, 663-670.

48. Farmer VC., Russell JD., The infrared spectra of layer silicates. Spectrochimca Acta., 1964, 20, 1149-1173.

49. Tantawy MA., Ahmed, SA., Abdalla, EM., Qassim MI., Immobilization of copper ions laden kaolin waste: influence of thermal treatment on its immobilization in cement paste. Journal of Material Cycles and Waste Management., 2016, 18(2), 263-272.

50. Liew, YM., Kamarudin, H., Al Bakri, AMM., Luqman, M., Khairul NI., Ruzaidi, CM., Heah, CY., Processing and characterization of calcined kaolin cement powder. Construction and Building Materials., 2012, 30, 794-802.

51. Madejova, J., Komadel, P., Baseline studies of the clay minerals society source clays: infrared methods. Clay Mineralogy., 2001, 49(5), 410-432.

52. Prost, R., Dameme, E., Driard, J., Leydecadsker, JP., Infrared study of structural
$\mathrm{OH}$ in kaolinite, dickite, nacrite, and poorly crystalline kaolinite at 5 to $600 \mathrm{~K}$. Clays and Clay Minerals., 1989, 37, 464-468.

53. Chen, HS., Sun, ZY., Shao, JC., Investigation on FT-IR spectroscopy for eight different sources of $\mathrm{SiO}_{2}$. Bulletin of Chinese Ceramic Society., 2011, 30, 934-937.

54. Moenke, HHW., Silica the three-dimentional silicates, borosilicates and beryllium silicates, in: C.V. Farmer (Ed.), The Infrared Spectra of Minerals. Adlard and Son, NY., 1974, 365.

55. Hemmings, RT., Berry, EE., On the glass in coal fly ashes: Recent advances. Materials Research Society Symposium Proceedings., 1988, 113, 3-39.

56. Ying, JY., Mechanical properties and deformation behavior of materials having ultra-fine microstructure. Kluwer Academic Publishers: Netherlands., 1993, 565-570.

57. Zu G., Shun J., Wei X., Ni X., Zhang Z., Wang J., Liu, G., Preparation and characterization of monolithic alumina aerogels. Journal of NonCrystalline Solids., 2011, 357, 2903-2906.

58. Knözinger, H., \& Ratnasamy P., Catalytic aluminas: Surface models and characterization of surface sites, Catalysis Reviews., 2007, 3, 31-70.

59. Aparicio, P., Galan, E., Valdre, G., Moro, D., Effect of pressure on kaolinite nanomorphology under wet and dry conditions, Correlation with other kaolinite properties. Applied Clay Science., 2009, 46, 202-208.

60. Konan, KL., Peyratout, C., Smith, A., Bonnet, JP., Rossignol, S. Oyetola, S., Comparison of surface properties between kaolin and metakaolin in concentrated lime solutions, Journal of Colloid Interface Science., 2009, 339, 103-109.

61. Lu, W., Chen, T., The effect $\mathrm{pH}$ on purification of $\mathrm{Fe}$ in the preparation of high purity $\mathrm{Al}_{2} \mathrm{O}_{3}$ by Crystallization. International Conference on Mechatronics, Electronic, Industrial and Control Engineering (MEIC-14), Advances in Engineering Research., 2014. 